\title{
Evaluation of The Analgesic Activity of Coenzyme Q10 Ointment in Mice
}

\author{
Ibtisam T. Al-Jureisy ${ }^{1}$, Wael T. Al-Wattar ${ }^{2}$ and Ghada A. Taqa ${ }^{3^{*}}$ \\ ${ }^{1}$ Ministry Of Health, Nineveh Health Directorate,Mosul, Iraq \\ ${ }^{2}$ Department of Oral and Maxillofacial Surgery, College of Dentistry, University of Mosul , Mosul, Iraq \\ ${ }^{3^{*}}$ Department of Dental Basic Science, College of Dentistry, University of Mosul, Mosul, Iraq. \\ * Corresponding author: Ghada A. Taqa; email: ghada.abd.taqa@gmail.com
}

\begin{abstract}
The aim of this study is to examine analgesic effect of Coenzyme Q10 ointment in mice. Fifteen healthy male albino mice were selected for this study. The animals were divided into three groups of five animals for each group. The pain reaction time was recorded pretreatment for each animal and was taken as a basal threshold(1). Group 1 served as a control and was applied Vaseline ointment topically on fore and hind limb. Group 2 and 3 were applied topically Coenzyme Q10 ointment 4\%, 8\% respectively on fore and hind limb. The onset and duration of analgesic effect of Coenzyme Q10 ointment were evaluated in mice by utilizing a Hot-Plate test at $55 \pm 1^{\circ} \mathrm{C}$. Latency reaction time was recorded after $3 \mathrm{~min}$. and $(10-60 \mathrm{~min})$ after ointment applied. The prolongation of latency times compared with the values of the control was used to express about analgesic effects of Coenzyme Q10 ointment and the percentage of antinociceptive ,Maximal Possible Effect (MPE) was calculated. The Coenzyme Q10 ointment at concentrations $(4 \%, 8 \%)$ produced analgesic effect in mice after $3 \mathrm{~min}$, respectively in comparison with control. The percentage of maximum possible effect (MPE) was significantly increased in group treated with $(4 \%, 8 \%)$ Coenzyme Q10. It can be concluded that, the Coenzyme Q10 ointment have a good analgesic activity in mice after 3 minutes of topical application and prolong the duration of analgesia more than 40 minutes depending on concentration of Coenzyme Q10 ointment.
\end{abstract}

Original Article:

DOI : https://dx.doi.org/10.21608/j vs.2019.20868.1001

Received 11 Dec., 2019

Accepted 22 Dec., 2019

Published in 09 Jan., 2020

This is an open access article under the term of the Creative Commons Attribution $\quad 4.0 \quad$ (CC-BY) International License . To view a copy of this license, visit http://creativecommons.org/licenses/ by/4.0/

Key words: Analgesia in mice, Coenzyme Q10 ointment, Hot-plate test, J. Appl. Vet. Sci., 5(1): 11-16. Maximal Possible Effect, Pain.

\section{INTRODUCTION}

Analgesics drugs are commonly prescribed for pain management (Curtero, et al., 2006). The analgesic drugs can be defied as a drug that relief, manages and treats pain (Dahl and Reader, 2000). Systemic administration of analgesic drug produces many side effects (Therefore it (of paramount importance) to develop non-oral dosage forms of analgesic drug to minimize the gastric pain , to persist for a long period at the site of application and to minimize the disadvantages of oral administration (Alarcon, 2002). Topical application of drug is considered the best route of administration because by passing through the skin, it has a large area for drug penetration with fast exposure to circulating and the route is noninvasive (Daniels and Knie, 2002) Coenzyme Q10 is a fat-soluble antioxidant compound which acts as a key element of the electron transport chain for cellular adenosine triphosphate (ATP) production (DiNicolantonio, et al., 2015) , in addition to that it has anti-inflammatory effect (Zhai, et al., 2017). The biosynthesis of CoQ10 takes place in the mitochondria of the liver, heart, kidneys and muscles, where they require a greater quantity of energy for their multiple biological roles (Acosta, et al., 2016).

The chemical structure of CoQ10 is similar to that of vitamin $\mathrm{K}, \mathrm{CoQ} 10$ is not considered a vitamin because it is the only lipid-soluble antioxidant that animal cells synthesize de novo in the body (Bhagavan and Chopra, 2006). Coenzyme Q10 is known to be a redox-active lipophilic antioxidant, scavenging reactive 
oxygen species ( ROS) and inhibiting lipid peroxidation in the body (Niklowitz, et al., 2004) .

The capability of CoQ10 to scavenge ROS is lot greater than vitamin $\mathrm{E}$ and it was also identified to facilitate the absorption of lipid soluble antioxidant vitamins such as vitamin A and E (Shekelle, et al., 2003). The research about analgesic activity of Coenzyme Q10 was very little. The aim of the present study is to prepare different concentration of Coenzyme Q10 ointment to examine the analgesic effects of topical application in mice by using a hot plate test.

\section{MATERIALS AND METHODS}

\section{Animals}

Fifteen healthy male albino mice weight about 20-30 gm with equal age were selected to use for this study. Mice were obtained from animal care housed in Dentistry Collage of Mosul University in Iraq. The animals were housed in plastic cages under $12 \mathrm{~h}$ light $12 \mathrm{~h}$ dark cycle at $22 \pm 2^{\circ} \mathrm{C}$ and access to fed with standard diet and tap water.

\section{Preparation of Coenzyme Q10 ointment}

Coenzyme Q10 ointment were prepared in two different concentration by mixing $(4,8) \mathrm{g}$ from Coenzyme Q10 powder in $100 \mathrm{gm}$ Vaseline respectively to give final concentration $(4 \%, 8 \%)$ $\mathrm{W} \backslash \mathrm{W}$ with continuous mixing using a glass rode until homogenous ointment were formed.The ointment were kept in plastic containers and stored in refrigerator at $4^{0} \mathrm{C}$ until used.

\section{Experiment On Animals}

The mice were divided into 3 groups; each group consisted of five animals. The pain reaction time was recorded pretreatment for each animal and was taken as a basal threshold. Group 1 served as a control and was applied vasaline ointment topically on fore and hind limb. However group 2 and 3 were applied Coenzyme Q10 ointment 4\%, 8\% respectively topically on fore and hind limb. The onset and duration of analgesic effect of Coenzyme Q10 ointment were evaluated in mice by utilizing a Hot-Plate test. Mice were placed on a hotplate maintained at $55 \pm 1^{\circ} \mathrm{C}$. The reaction time is that between placing the animals on the hot-plate and holding, jumping, licking of the fore or hind paws.
A cut off time of 30 seconds is followed to avoid any thermal injury to the paws (Ghosh, 1984). Latency reaction time was recorded after $3 \mathrm{~min}$. and $(10,20,30,40,50,60 \mathrm{~min}$.) following topically applied of Coenzyme Q10 ointment in treated group and ointment only in control group by using hotplate test to assess the onset and duration of treated ointment. The prolongation of latency times compared with the values of the control was used to express about antinociceptive effects of Coenzyme Q10 ointment. The percentage of antinociceptive Maximal Possible Effect (MPE) was calculated from the formula: (Giusti, 1997)

$\% \mathrm{MPE}=($ Test latency- predrug latency/cut off timepredrug latency) $\times 100$

MPE means Percentage of antinociception maximal possible effect.

Test latency means Second after drug treatment.

Predrug latency means Second before drug treatment at zero time.

Cut off time means 30 second.

\section{Statistical Analysis}

The data were expressed as mean $\pm \mathrm{SD}$, difference between three experimental groups were statistically analyzed by one way analysis of variance (ANOVA) followed by the Duncan. The level of significance was at $\mathrm{p}<0.05$.

\section{RESULTS}

In the present study, the Coenzyme Q10 drug was evaluated for its antinociceptive activity against pain induced by hot-plate in mice. Topical application of Coenzyme Q10 drug at $(4 \%, 8 \%)$ create good analgesic effects in comparison with control treated with Vaseline only. The results for increasing the pain reaction time of the Coenzyme Q10 drug at (4\%) and (8\%) showed that the drug has a highly significant difference after ( 3 and 10, 20, 30, 40,50,60) min. The maximum pain reaction time at 30 second after drug application (Table 1).

Reaction time (antinociceptive) was augmented from $0 \%$ in control group after 3 min. to (5.08, $15.87) \%$ respectively according to the concentration of Coenzyme Q10 at (4\% and 8\%). In the hot plate test, the percentage of reaction time (antinociceptive) in concentration of Coenzyme Q10 drug at $4 \%$ increased according to the time (Table 2 and Fig. 1). 
Ibtisam.T.Al-Jureisy et al......

Table 1: The pain reaction time of Coenzyme Q10(4\%, 8\%) topically in mice.

\begin{tabular}{|l|c|c|c|c|c|c|}
\hline \multicolumn{1}{|c|}{ Group } & $+3 \mathrm{~min}$ & $+10 \mathrm{~min}$ & $+20 \mathrm{~min}$ & $+30 \mathrm{~min}$ & $+40 \mathrm{~min}$ & $+50 \mathrm{~min}$ \\
\hline Control & $4.3 \pm 0.5^{\mathrm{a}}$ & $4.3 \pm 0.5^{\mathrm{a}}$ & $4.3 \pm 0.5^{\mathrm{a}}$ & $4.3 \pm 0.5^{\mathrm{a}}$ & $4.3 \pm 0.5^{\mathrm{a}}$ & $4.3 \pm 0.5^{\mathrm{a}}$ \\
\hline $\begin{array}{l}\text { Coenzyme Q10 } \\
\text { ointment (4\%) }\end{array}$ & $5.0 \pm 0.0^{\mathrm{a}}$ & $5.3 \pm 0.5^{\mathrm{a}}$ & $7.0 \pm 1.0^{\mathrm{b}}$ & $8.0 \pm 1.0^{\mathrm{b}}$ & $6.0 \pm 1.0^{\mathrm{a}}$ & $4.6 \pm 1.1^{\mathrm{a}}$ \\
\hline $\begin{array}{l}\text { Coenzyme Q10 } \\
\text { ointment (8\%) }\end{array}$ & $7.0 \pm 1.0^{\mathrm{b}}$ & $8.3 \pm 0.5^{\mathrm{b}}$ & $11 \pm 1.7^{\mathrm{c}}$ & $12.0 \pm 2.0^{\mathrm{c}}$ & $9.0 \pm 1.0^{\mathrm{b}}$ & $8.3 \pm 0.5^{\mathrm{b}}$ \\
\hline
\end{tabular}

$\mathrm{Abc}^{\mathrm{A}}$ : The horizontal different letters means significant difference by Duncan at $\mathrm{p}<0.05$.

Table 2: Effect of Coenzyme Q10 (4\%,8\%) topically on antinociceptive maximum possible effect (MPE\%) in hot plate test in mice.

\begin{tabular}{|l|l|l|l|l|l|l|}
\hline Group & $3 \mathrm{~min}$ & $10 \mathrm{~min}$ & $20 \mathrm{~min}$ & $30 \mathrm{~min}$ & $40 \mathrm{~min}$ & $50 \mathrm{~min}$ \\
\hline Control & 0 & 0 & 0 & 0 & 0 & 0 \\
\hline Coenzyme Q10 ointment (4\%) & 5.08 & 5.08 & 12.68 & 16.47 & 8.88 & 3.79 \\
\hline Coenzyme Q10 ointment (8\%) & 15.87 & 19.53 & 30.50 & 34.16 & 23.18 & 20.73 \\
\hline
\end{tabular}

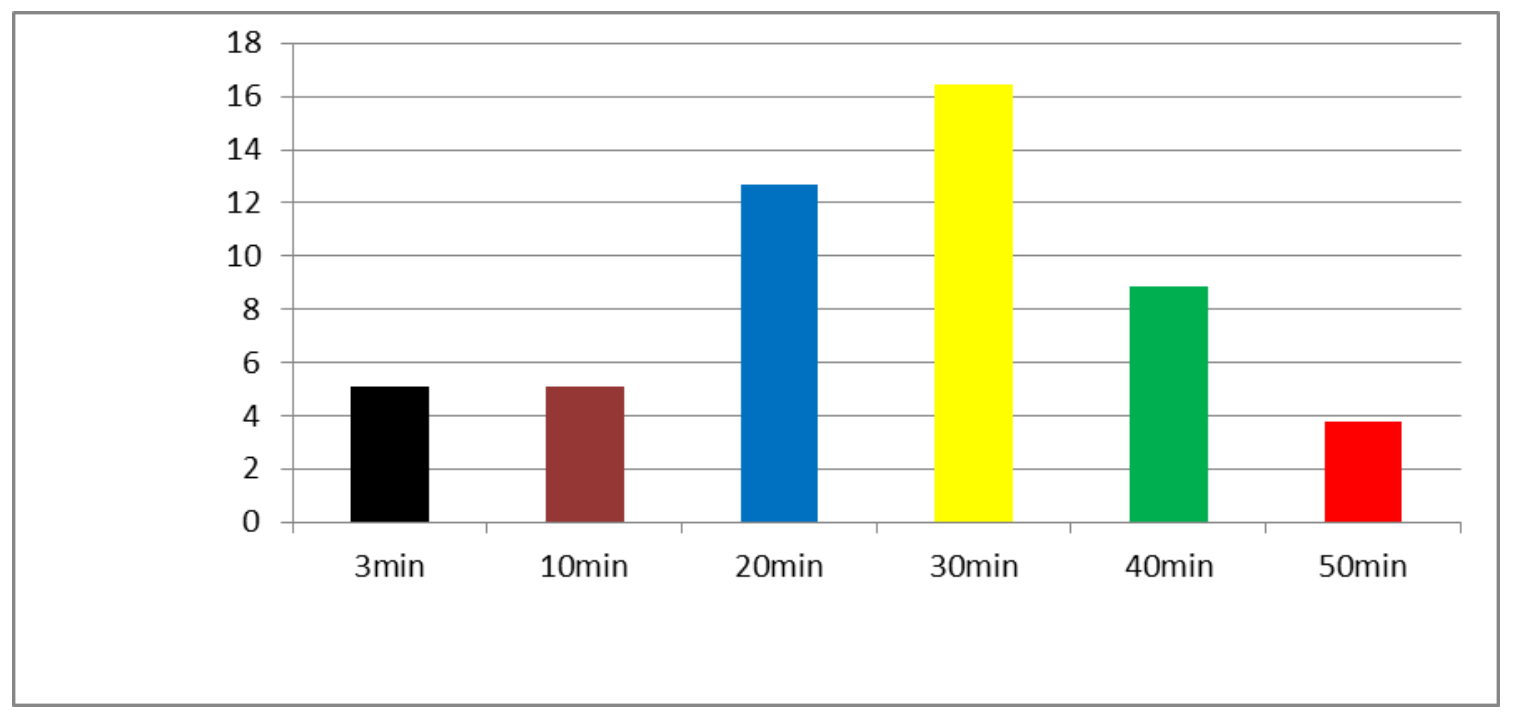

Fig. 1: Effect of Coenzyme Q10 4\% topically on antinociceptive maximum possible effect (MPE) in hot plate test in mice.

In concentration of Coenzyme Q10 drug at $8 \%$ the (MPE) increased to $(15.87,19.53,30.50,34.16,23.18$, 20.73) respectively according to time (Figure 2). While the maximum effect (best time) action of Coenzyme Q10 drug always happen at 30 min. in different concentration $(4 \%, 8 \%)$ as shown in Table 2and Figure 3. 


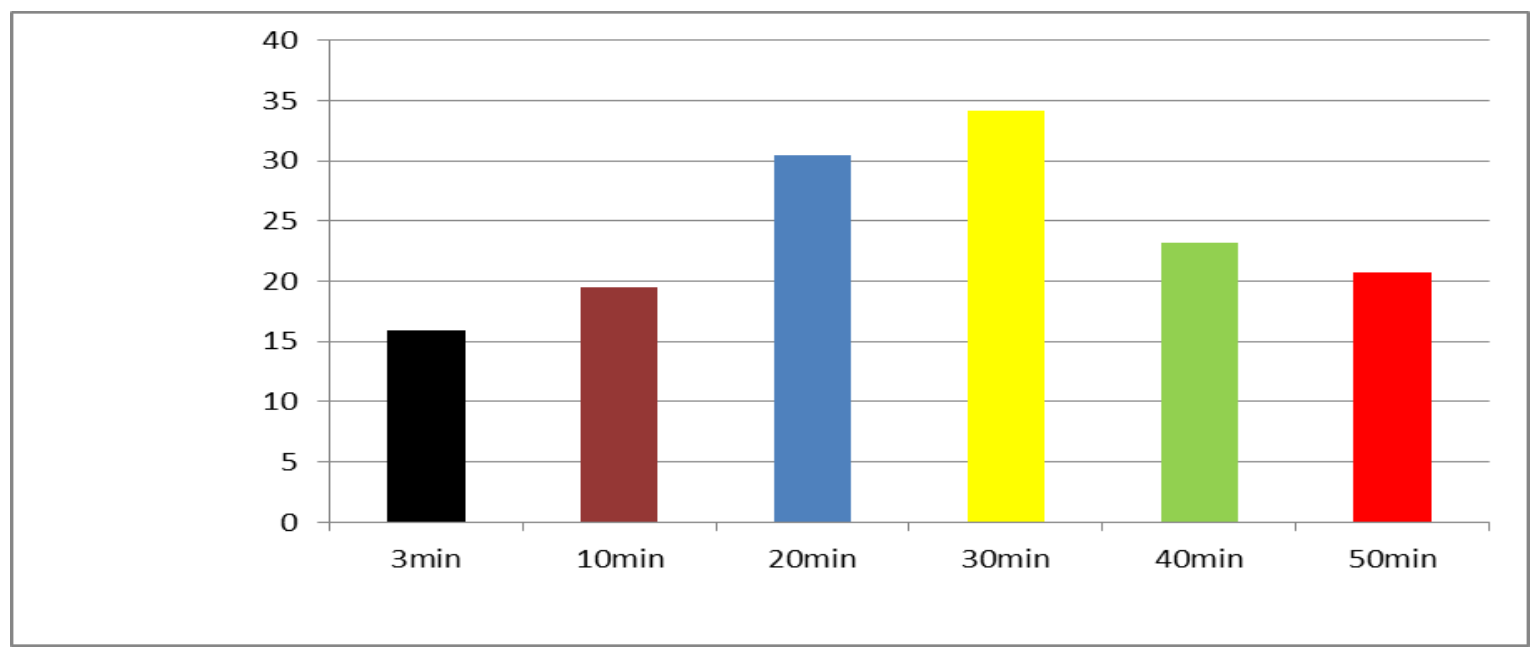

Fig. 2: Effect of Coenzyme Q10 8\% topically on antinociceptive maximum possible effect (MPE) in hot plate test in mice.

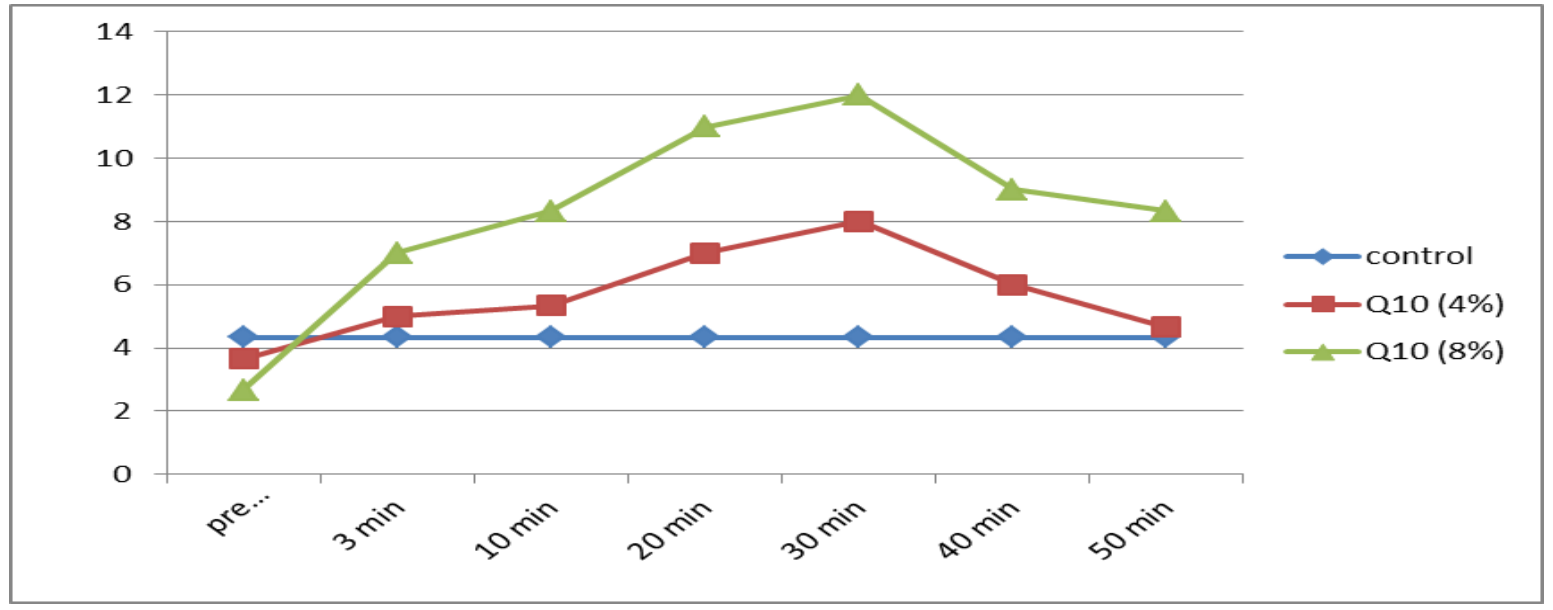

Fig. 3: Duration of analgesic activity of Coenzyme Q10 (4\% and 8\%) after topical application.

\section{DISCUSSION}

Topical analgesics drugs application have many advantages such as the ability to provide good analgesia with reduced systemic drug levels (Kreitler and Niv, 2007), remains for long period at the application site and enough drug penetration and high effective are other advantages(Illum, et al., 1994; Wael, 2011; Ghada, 2014).

In present study we found that Q10 have analgesic activity after using as a topical application at $(4 \%, 8 \%)$ ointment. The analgesic activity of Q10 in the present study may be return to the effect of Coenzyme Q10 on reducing inflammatory mediator (Nesami, et al., 2015). Pain generating pro-inflammatory cytokines including 1L-1ß and IL-6 (Kapoor, et al., 2011). IL-1 $\beta$ was found to increase the production of substance $P$ and prostaglandin $\mathrm{E}_{2}\left(\mathrm{PGE}_{2}\right)$ in a number of neuronal and glial cells (Jeanjean, et al., 1995; Schweizer, et al., 1988). IL-6 contributes to the development of neuropathic pain behavior following a peripheral nerve injury (DeLeo and Colburn, 1995; Ramer, 1998). TNF- $\alpha$ can enhance the sensitivity of sensory neurons to the excitation produced by capsaicin and this enhancement likely is mediated by the neuronal production of prostaglandins (Nicol, et al., 1997).

The anti-inflammatory function of CoQ10 However, it remains unclear what is their mechanism of action (Lee, et al., 2012). Several potential mechanisms might partially explain it. It seemed that CoQ10 might play a potential role in decreasing the production of pro-inflammatory cytokines by inhibiting NF- $\kappa \mathrm{B}$ gene expression (Schmelzer, et al.,2008), attenuating miR-146a and IL-1 receptor associated kinase modulation (Olivieri, et al., 2013), and reducing the secretion of macrophage 
inflammatory protein-1 alpha and regulated upon activation normal T-cell expressed and secreted factors (Schmelzer, et al., 2007). In addition, several studies observed a negative relationship between adiponectin and inflammatory factors (TNF- $\alpha$, IL-6, hs-CRP) (Engeli, et al., 2003; Zhou, et al., 2011).

Zhou et.al (2011) reported that adiponectin can inhibit stimulated monocytes secreting $\mathrm{TNF}-\alpha$ (Zhou, et al., 2011), so it is likely to that increasing in adiponectin which obtained by using of coenzyme Q10 (Farsi, et al., 2016; Nesami, et al., 2015) can indirectly bring about aplunge in inflammatory factors such as TNF- $\alpha$. Tsai et al. represented that CoQ10 suppresses iNOS and protect endothelial cells from oxidative stress-induced injury (Tsai, et al., 2012). Therefore CoQ10 reduced the pain (Jennifer, et al., 2013). Co enzyme $Q 10$ is a potent antioxidant and reduces oxidative stress by reduction of the reactive oxygen species (ROS) production (Ernster L, Dallner, 1995; Ferrante, et al., 2002).

The reactive oxygen species (ROS) are also involved in NMDA receptor phosphorylation, which leads to activation of NMDA receptors in nerve injury models (Siniscalco, et al., 2007; Muscoli, et al., 2004). Activation of NMDA receptors is another mechanism for induction of hyperalgesia seen after nerve injury (Wang, et al., 2004). Activation of NMDA receptors following excessive production of ROS could also lead to decrease in the antioxidant activity (Coyle and Puttfarcken, 1993). the role of CoQ10 is more emphasized.

\section{CONCLUSION}

Topical Coenzyme Q10 is an alternative dosage form, it is easy to apply, safe and not irritant. Because of the Coenzyme Q10 having all these above mechanisms, our study showed that Coenzyme Q10 have a good analgesic effect on the pain stimulated by using the hot-plate test in mice.

\section{REFERENCES}

ACOSTA MJ, VAZQUEZ FONSECA L, DESBATS MA, CERQUA C1, ZORDAN R, TREVISSON E AND SALVIATI L.2016. Coenzyme Q Biosynthesis in Health and Disease. Biochim Biophys Acta 1857(8): 1079-1085.

ALARCON E.2002. A comparative study of the transdermal penetration of a series of non steroidal anti-inflmmatory drugs. J Pharm Sci 86 (24)503-308.

BHAGAVAN H. N. AND CHOPRA R. K. 2006. Coenzyme Q10: Absorption,Tissue uptake, Metabolism and Pharmacokinetics. Free Radic Res 40(5), 445-53.
COYLE JT AND PUTTFARCKEN P.1993. Oxidative stress, glutamate, and neurodegenerative disorders. Science. 262(5134) : 689 -95.

CURTERO M, CARRIE H, MALIC U, ROMIC K, TASIOS B AND WU M. 2006. A comparision of frequently prescribed analgesics at the university of Toronto for postoperative pain following dental surgery. an evidancer-based study of the literature. Community Dentistry; $1: 1-12$.

DAHL V AND READER JC.2000. Non-opioid postoperative analgesia. J Acta Anaesthesiol Scand;44:1191-1203.

DANIELS R AND KNIE U.(2002). Galenics of dermal product, vehicles, properties and drug release. JDDG 5:367-38.

DELEO JA AND COLBURN RW.1995. The role of cytokines in nociception and chronic pain. In: Weinstein JN, Gordon SL, editors. Low Back Pain: A scientific and clinical overview. American Academy of Orthopaedic Surgeons pp. 163-185.

DINICOLANTONIO JJ, BHUTANI J, MCCARTY MF AND O'KEEFE JH.2015. Coenzyme Q10 for The Treatment of Heart Failure: A review of The Literature. Open Heart; 2: e000326.

ENGELI S, FELDPAUSCH M, GORZELNIAK K, HARTWIG F, HEINTZE U AND JANKE J, ET AL.2003. Association between adiponectin and mediators of inflammation in obese women. Diabetes. 52(4): 942-947.

ERNSTER L AND DALLNER G.1995. Biochemical, physiological and medical aspects of ubiquinone function. Biochim Biophys Acta. 1271(1) : 195 -204.

FARSI F, MOHAMMADSHAHI M, ALAVINEJAD P, REZAZADEH A, ZAREI M AND ENGALI KA.2016. Functions of Coenzyme Q10 Supplementation on Liver Enzymes, Markers of Systemic Inflammation, and Adipokines in Patients Affected by Nonalcoholic Fatty Liver Disease: A Double-Blind, Placebo-Controlled, Randomized Clinical Trial. J Am Coll Nutr.35(4): 346-353.

FERRANTE RJ, ANDREASSEN OA, DEDEOGLU A, FERRANTE KL, JENKINS BG AND HERSCH SM, ET AL.2002. Therapeutic effects of coenzyme Q10 and remacemide in transgenic mouse models of Huntington's disease. J Neurosci.22(5) : 1592 -9.

GHADA A. TAQA.2014. Evaluation of antinociceptive activity of ketamine cream in rats. Human and Veterinary Medicine.

GHOSH MN.1984. Fundamental of experimental pharmacology. Scientifibook Agency Calcutta, 2nd edition, p. 44-145.

GIUSTI G.1997. The categorical status of determiners. In The New Comparative Syntax, New York: Longman Publishing Group, ed. L. Haegeman.pp. 95-123.

ILLUM L, FARRAJ NF AND DAVIS S.1994. Chitosan as a novel nasal delivery system for peptide drugs. Pharm Res 11:1186-9.

JEANJEAN AP, MOUSSAOUI SM AND MALOTEAUX JM, ET AL(1995. Interleukin-1 beta induces long-term increase of axonally transported opiate receptors and substance $P$. Neuroscience 68:151-157. 
JENNIFER LEE, YEON SIK HONG, JEONG HEE JEONG, EUN JI YANG, JOO YEON JHUN, MI KYOUNG PARK, YOUNG OK JUNG, JUN KI MIN, HO YOUN KIM, SUNG HWAN PARK AND MI-LA CHO.2013. Coenzyme Q10 Ameliorates Pain and Cartilage Degradation in a Rat Model of Osteoarthritis by Regulating Nitric Oxide and Inflammatory Cytokines.

KAPOOR M, MARTTEL-PELLETIER J, LAJEUNESSE D, PELLETIER JP AND FAHMI H. 2011. Role of proinflammatory cytokines in the pathophysiology of osteoarthritis. Nat Rev Rheumatol 7:33-42.

KREITLER S AND NIV D.(2007).Cognitive impairment in chronic pain. Pain Clinical Updates XV(4):1-4.

LEE BJ, HUANG YC, CHEN SJ AND LIN PT.2012. Effects of coenzyme Q10 supplementation on inflammatory markers (high-sensitivity C-reactive protein, interleukin-6, and homocysteine) in patients with coronary artery disease. Nutrition. 28(7-8): 767772.

MUSCOLI C, MOLLACE V, WHEATLEY J, MASINI E, NDENGELE M AND WANG ZQ, ET AL.2004. Superoxide-mediated nitration of spinal manganese superoxide dismutase: a novel pathway in N-methylD-aspartate-mediated hyperalgesia. Pain. 111(1-2) : $96-103$.

NESAMI BN, MOZAFFARI-KHOSRAVI H, NAJARZADEH A AND SALEHIFAR E.2015. The Effect of Coenzyme Q10 Supplementation on ProInflammatory Factors and Adiponectin in Mildly Hypertensive Patients: A Randomized, Double-Blind, Placebo-Controlled Trial. Int J Vitam Nutr Res. 85(34): 156-164.

NICOL GD, LOPSHIRE JC AND PAFFORD CM.1997. Tumor necrosis factor enhances the capsaicin sensitivity of rat sensory neurons. J Neurosci. 17:975982.

NIKLOWITZ P, MENKE T, ANDLER W AND OKUN JG.2004. Simultaneous analysis of coenzyme Q10 in plasma, erythrocytes and platelets:comparison of the antioxidant level in blood cells and their environment in healthy children and after oral supplementation in adults. Clin Chim Acta 342: 219-226.

OLIVIERI F, LAZZARINI R, BABINI L, PRATTICHIZZO F, RIPPO MR AND TIANO L,ET AL.2013.Anti-inflammatory effect of ubiquinol-10 on young and senescent endothelial cells via miR-146a modulation. Free Radic Biol Med.63: 410-420.

RAMER MS, MURPHY PG AND RICHARDSON PM, ET AL.1998. Spinal nerve lesion-induced mechanoallodynia and adrenergic sprouting in sensory ganglia are attenuated in interleukin-6 knockout mice. Pain 78:115-121.

SCHMELZER C, LINDNER I, RIMBACH G, NIKLOWITZ P, MENKE T AND DO"RING F.2008. Functions of coenzyme Q10 in inflammation and gene expression. Biofactors. 32(1-4): 179-183.

SCHMELZER C, LORENZ G, RIMBACH G AND DORING F.(2007). Influence of Coenzyme Q_ $\{10\}$ on release of pro-inflammatory chemokines in the human monocytic cell line THP-1. Biofactors.31(34): 211-217.

SCHWEIZER A, FEIGE U AND FONTANA A, ET AL.1988. Interleukin-1 enhances pain reflexes. Mediation through increased prostaglandin E2 levels. Agents \& Actions. 25:246-251.

SHEKELLE P, MORTON S AND HARDY ML.2003. Effect of supplemental antioxidants vitamin C, vitamin $\mathrm{E}$, and coenzyme Q10 for the prevention and treatment of cardiovascular disease. Evid Rep Technol Assess (Summ); 83: 1-3.

SINISCALCO D, FUCCIO C, GIORDANO C, FERRARACCIO F, PALAZZO E AND LUONGO L, ET AL.2007. Role of reactive oxygen species and spinal cord apoptotic genes in the development of neuropathic pain. Pharmacol Res. 55(2) : $158-66$.

TSAI KL, HUANG YH, KAO CL, YANG DM AND LEE HC, ET AL. 2012. A novel mechanism of coenzyme Q10 protects against human endothelial cell from oxidative stree-induced injury by modulating NO-related pathway.J Nutr Biochem 23:458-468.

WAEL T. AL-WATTAR.2011. The Efficacy of Triamcinalone in Controlling Pain and Swelling after Surgical Extraction of Teeth. Al-Rafidain Dent J. 11(1);32-36.

WANG ZQ, PORRECA F, CUZZOCREA S, GALEN K, LIGHTFOOT R AND MASINI E, ET AL.2004. A newly identified role for superoxide in inflammatory pain. J Pharmacol Exp Ther.309(3): $869-78$.

ZHAI J, BO Y, LU Y, LIU C AND ZHANG L.2017. Effects of Coenzyme Q10 on markers of inflammation: A systematic review and meta-analysis. PloS one. 12: e0170172.

ZHOU Y, WEI Y, WANG L, WANG X, DU X AND SUN Z, ET AL.2011. Decreased adiponectin and increased inflammation expression in epicardial adipose tissue in coronary artery disease. Cardiovasc Diabetol. 10(1):1-9: 2.

How to cite this article:

Ibtisam T. Al-Jureisy, Wael T. Al-Wattar and Ghada A. Taqa., 2020. Evaluation Of The Analgesic Activity Of Coenzyme Q10 Ointment In Mice. Journal of Applied Veterinary Sciences, 5(1): 11-16.

DOI:https://dx.doi.org/10.21608/javs.2019.20868.1001 